range $0.02-2.0 \mathrm{~mm}$. Widely differing concentrations of sodium and potassium (up to 50:1 or $1: 50$ ) were estimated in a single dilution, and in one spraying, less than $2 \mathrm{ml}$. of the diluted sample being consumed.

\section{DISCUSSION}

The mutual interference between sodium and potassium observed in the acetylene/air flame (Domingo \& Klyne, 1949; Leyton, 1951; Smit, Alkemade \& Verschure, 1951; Baker, 1955) is avoided by the use of the cooler illuminating-gas/ air flame (Alkemade, Smit \& Verschure, 1952), which simplifies the determinations. The internalstandard procedure is preferred to direct reading, because the instrumental stability and the precision of a single reading are greater (Berry et al. 1946; Spencer, 1950; Bernstein, 1952; Baker, 1955), which makes multiple sprayings of the same sample unnecessary. The reading is unaltered by $\pm 25 \%$ variation in spraying rate, which was in practice the most difficult variable to control in direct reading (Leyton, 1951). The lithium internal standard has been reported to compensate for interferences by many substances (Berry et al. 1946; Spencer, 1950; Bernstein, 1952); this has been verified for the components of our own samples.

\section{SUMMARY}

1. The design and operation of a simple lithium internal-standard flame photometer are described.

We are very grateful to Mr J. T. Cox for building the apparatus and for devising the atomizer, to $\mathrm{Mr} H$. Vincent for evolving the spray chamber, and to Mr A. Renshaw and Mr D. Sproat for assistance. We also thank Dr A. Leaf, Mr M. P. Esnouf and Mr D. Exley for advice and help. One of us (W.C.W.) is a Research Fellow of the National Cancer Institute, U.S. Public Health Service.

\section{REFERENCES}

Alkemade, C. T. J., Smit, J. \& Verschure, J. C. M. (1952). Biochim. biophys. Acta, 8, 562.

Baker, R. W. R. (1955). Biochem. J. 59, 566.

Bernstein, R. E. (1952). Biochim. biophys. Acta, 9, 576.

Berry, J. W., Chappell, D. G. \& Barnes, R. B. (1946). Industr. Engng Chem. (Anal.), 18, 19.

Domingo, W. R. \& Klyne, W. (1949). Biochem. J. 45, 400. Leyton, L. (1951). Analyst, 76, 723.

Smit, J., Alkemade, C. T. J. \& Verschure, J. C. M. (1951). Biochim. biophys. Acta, 6, 508.

Spencer, A. G. (1950). Lancet, 259, 623.

\title{
Studies on the Biosynthesis of Cholesterol*
}

\section{COENZYME REQUIREMENTS OF LIVER ENZYMES FOR SYNTHESIS OF SQUALENE AND OF STEROL FROM DL-3-HYDROXY-3-METHYL-[2-14 C]PENTANO-5-LACTONE}

\author{
By G. POPJÁK, L. GOSSELIN, $†$ IRENE YOUHOTSKY GORE AND R. G. GOULD \\ M.R.C. Experimental Radiopathology Research Unit, Hammersmith Hospital, \\ Ducane Road, London, W. 12
}

(Received 20 December 1957)

\begin{abstract}
The synthesis of cholesterol from 3-hydroxy-3methylpentano-5-lactone (mevalonic acid) was discovered by Tavormina, Gibbs \& Huff (1956) and the high yield of labelled sterol from the DL-[2-14C]mevalonic acid incubated with liver preparations has been confirmed (Cornforth, Cornforth, Popják $\&$ Gore, 1957, 1958). It was further shown $(a)$ that mevalonic acid is also an effective precursor of squalene, $(b)$ that all the carbon atoms of the acid maintain their individuality during biosynthesis, and (c) that five of its carbon atoms (C-2, C-3,

* Part 5: Cornforth, Cornforth, Popják \& Gore (1958)

$\dagger$ Aspirant du Fonds National de la Recherche Scientifique, Belgium.

$\ddagger$ Participated in the early part of this work during tenure of a United States Public Health Service Special Research Fellowship, and while on leave of absence from the Los Alamos Scientific Laboratory of the University of California, Los Alamos, New Mexico.
\end{abstract}

3-Me, C-4 and C-5) provide the isoprenoid units in the biosynthesis of squalene and hence of sterol (Cornforth et al. 1957, 1958).

This paper deals with the identification of the various coenzymes required by liver-enzyme preparations for the synthesis of squalene and of sterol from mevalonic acid. A brief account of this work has already been given (Popják, Gosselin \& Gore, 1958; Gould \& Popják, 1957).

\section{METHODS}

The following abbreviations will be used in addition to those noted in the text: diphosphopyridine nucleotide (DPN) and its reduced form (DPNH); triphosphopyridine nucleotide (TPN) and its reduced form (TPNH); adenosine triphosphate (ATP); coenzyme A (CoA or CoA-SH); cysteine (CySH); glutathione (GSH); $p$-chloromercuribenzoate (PCMB). 
Homogenates. These were prepared from the liver of young rats according to Bucher \& McGarrahan (1956) in $0 \cdot 1 \mathrm{~m}$-potassium phosphate buffer, $\mathrm{pH} 7 \cdot 4$, containing $0.03 \mathrm{M}$-nicotinamide and $0.004 \mathrm{M}-\mathrm{MgCl}_{2}$, or in $0.154 \mathrm{M}-\mathrm{KCl}$ buffered ( $\mathrm{pH} \mathrm{7 \cdot 6)}$ with $0.01 \mathrm{M}-2$-amino-2-hydroxymethyl propane-1:3-diol hydrochloride (tris) and containing nicotinamide $(0.03 \mathrm{M})$ and $\mathrm{MgCl}_{2}(0.004 \mathrm{M})$. The phosphate buffer containing nicotinamide and $\mathrm{MgCl}_{2}$ will be referred to as 'standard buffer' and the other one as ' $\mathrm{KCl}-$ tris buffer'. Details of our procedure of homogenizing were given previously (Cornforth et al. 1958). Cell debris and nuclei were removed by centrifuging for $15 \mathrm{~min}$. at $700 \mathrm{~g}$; from the 'homogenate' thus obtained the mitochondria were sedimented at $10000 \mathrm{~g}$ for $25 \mathrm{~min}$. The preparation from which the mitochondria were removed will be designated $S_{10}$. The $S_{10}$ preparations were further fractionated by centrifugation in a Spinco Model $\mathrm{L}$ preparative high-speed centrifuge. When the turbid $S_{10}$ fractions were centrifuged at a mean force of $104000 \mathrm{~g}$ for $1 \mathrm{hr}$., the following layers were obtained: (1) a thin film of fat on the surface; (2) a clear transparent pink supernatant of soluble proteins $\left(\mathrm{S}_{104}\right)$; (3) a gelatinous and loosely sedimented pinkish brown layer of particles ('light' microsomes); and (4) a crystal-clear transparent, straw-coloured and tightly packed pellet at the bottom of the centrifuge tube ('heavy' microsomes). There was not even a trace of other particles below this last layer, indicating that the mitochondria were completely removed at $10000 \mathrm{~g}$. The $S_{104}$ supernatant was pipetted off, care being taken not to disturb the sedimented particles. The 'light' microsomal layer could be separated from the heavier one by the addition of $1 \mathrm{ml}$. of buffer and shaking of the centrifuge tubes; the lighter layer usually peeled off cleanly from the transparent heavier layer. Both the 'light' and 'heavy' microsomes were resuspended, by the use of a small glass homogenizer, in a volume of buffer equal to about one-quarter of the original volume of $S_{10}$. They were then sedimented again at $104000 \mathrm{~g}$ for $40 \mathrm{~min}$. The supernatants from this second centrifuging of the microsomes were discarded. The washed microsomes were diluted with standard buffer to a volume equal to one-tenth the volume of the $S_{10}$ from which they were separated and were finely dispersed with the help of a homogenizer. Microsomes thus washed were used in the experiments. The suspension of 'light' microsomes when viewed in a Hartridge reversion spectroscope showed the characteristic absorption bands of cytochrome $b_{5}$ (Strittmatter \& Ball, 1954) which could also be demonstrated in dilute preparations with a Beckman recording spectrophotometer; no other cytochrome bands could be seen. Faint absorption bands of oxyhaemoglobin were detectable in thick suspensions of 'light' microsomes after oxygenation. The 'heavy' microsomal layer contained no haem pigment, but proved to be very rich in glycogen. Unless they are otherwise specified we shall denote as microsomes the lighter fraction. Although the microsomes could be kept at $-15^{\circ}$ for a few days without serious loss of enzyme activity, their preservation at low temperature was uncertain, activity being lost from some preparations sooner than from others. Because of this uncertainty, microsomes were prepared on the day of each experiment.

Preparation of soluble enzymes from $\mathrm{S}_{104}$. The $\mathrm{S}_{104}$ supernatant was brought to about $90 \%$ saturation by the addition of $6 \cdot 3 \mathrm{~g}$. of solid ammonium sulphate to every $10 \mathrm{ml}$. of $\mathrm{S}_{104}$. The precipitated proteins were filtered off overnight; the protein sludge was 'dried' by pressing between layers of filter paper and then scraped off. Active preparations could be made from this sludge even after several weeks of storage at $-15^{\circ}$ by dissolving $3 \mathrm{~g}$. of sludge in $12 \mathrm{ml}$. of $0.02 \mathrm{M}-\mathrm{KHCO}_{3}$ and by dialysing the protein against $0.02 \mathrm{M}-\mathrm{KHCO}_{3}$ solution for $2-3 \mathrm{hr}$. A small amount of insoluble protein was centrifuged off at $10000 \mathrm{~g}$ for $5 \mathrm{~min}$. Such preparations usually contained $35-50 \mathrm{mg}$. of protein/ $\mathrm{ml}$., as determined by the biuret reaction (Gornall, Bardawill \& David, 1949). The protein content of $S_{104}$ was usually 25-28 mg./ml.

Coenzymes. A crude coenzyme preparation was made by heating fresh $\mathrm{S}_{104}$ preparations in a boiling-water bath for 5 min. and by filtering off the coagulated proteins by suction on a sintered-glass funnel. Such coenzyme preparations will be denoted as.'boiled extracts'; they varied somewhat in potency; they were generally deficient in pyridine nucleotides.

The sources of purified coenzymes (DPN, DPNH, TPN, ATP, CoA) and of alcohol dehydrogenase were given in a previous communication (Hele, Popják \& Lauryssens, 1957). Cysteamine ( $\beta$-mercaptoethylamine) was the generous gift of Horlicks Ltd.

$\mathrm{DL}-\left[2-{ }^{14} \mathrm{C}\right]$ Mevalonic acid. This was synthesized by Dr Rita H. Cornforth as described previously (Cornforth et al. 1957, 1958). Two batches were available, one with a specific activity of $0.048 \mu \mathrm{c} / \mu$ mole and another of $0.2 \mu \mathrm{c} /$ $\mu$ mole.

Incubations. These were done in small conical flasks at 37-38 in Warburg baths. During anaerobic incubations the flasks were flushed continuously with $\mathrm{N}_{2}$. When sterols were examined, $1 \mathrm{mg}$. of cholesterol in $1 \mathrm{ml}$. of ethanol was added to the flasks at the end of the incubation period. When the synthesis of squalene was studied $10 \mathrm{mg}$. of squalene was added to the flasks at the start or at the end of incubations. The enzyme mixtures were saponified at the end of incubation at about $70^{\circ}$ for $1 \mathrm{hr}$. after addition of $1 \mathrm{ml}$. of aq. $40 \%(\mathrm{w} / \mathrm{v}) \mathrm{KOH}$. The extraction of the nonsaponifiable matter and separation of squalene and of sterol were done as described previously (Popják, 1954). The sterols were precipitated as the digitonides without further characterization; usually 6-7 mg. of digitonides was obtained from each flask.

As the cofactor requirements in squalene and sterol synthesis became better known, a fixed incubation mixture was devised; this consisted of dialysed soluble enzyme (S, $1 \mathrm{ml}$.) + suspension of washed microsomes $(0.2 \mathrm{ml})+$. DPNH $\quad(1 \mu \mathrm{mole})+$ TPN $\quad(0.5 \mu$ mole $)+$ ATP $\quad(10 \mu$ moles $)$

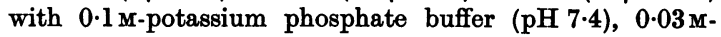
nicotinamide and $4 \mathrm{~mm}-\mathrm{MgCl}_{2}$. In several tables this mixture is referred to as the 'standard incubation mixture' to which additions were made as required; the final volume was $4 \mathrm{ml}$.

Assays of ${ }^{14} \mathrm{C}$. These were done on solid samples as described previously (Popják, 1950). All counts were corrected to infinite thickness and compared with a poly $\left[{ }^{14} \mathrm{C}\right]$ methyl methacrylate standard of the same area $\left(2 \mathrm{~cm} .{ }^{2}\right)$ as that of the samples. The standard had a specific activity of $1 \mu \mathrm{c} / \mathrm{g}$. and gave 1250 counts $/ \mathrm{min}$. at infinite thickness. The yields of conversion of MVA into squalene and sterol were calculated from the specific activities and the amounts of these products isolated. In those experiments in which some of the yields were low, the results are given as the specific activity of the products rather than as $\mu$ moles of MVA utilized in order to avoid the use of very small decimal fractions. 


\section{RESULTS}

\section{Components of homogenates required for synthesis of sterol from mevalonic acid}

As a preliminary step to the identification of the coenzymes involved in sterol synthesis we examined the various fractions of homogenates, obtained by centrifuging, for enzyme activity by ascertaining what fractions were required for synthesis of sterol from mevalonic acid. Since the sterols were isolated as the digitonides only, we cannot say whether the enzyme systems used have formed cholesterol exclusively or some other $3 \beta$ hydroxy sterols, such as lanosterol, as well. For this reason we shall refer to the process studied as sterol synthesis.

It has been reported previously (Cornforth et al. 1957, 1958; Gould \& Popják, 1957) that mitochondria are not required for sterol synthesis from mevalonic acid just as when acetate is used as precursor (Bucher \& McGarrahan, 1956). We shall therefore confine our attention to preparations of $\mathrm{S}_{10}$ (supernatant of homogenates centrifuged at $10000 \mathrm{~g}$ ) and fractions thereof.

Table 1 shows that only the $S_{10}$ preparation or the combination of $\mathrm{S}_{104}$ with 'light' microsomes was effective in synthesizing sterol. The slight activity that was observed when 'heavy' microsomes were added to the $\mathrm{S}_{104}$ may probably be attributed to contamination of the heavier particles with the lighter ones. In subsequent experiments the microsomes referred to will always mean the lighter fraction alone. Although the $S_{104}$ fraction by itself could not form sterol, it could synthesize some squalene, but much less efficiently than the full system containing microsomes. The $\mathrm{S}_{104}$ preparation $(2.5 \mathrm{ml}$.) used for the experiment recorded in Table 1 converted $0.068 \mu$ mole of mevalonic acid into squalene. We think that this squalene-synthesizing system is provided by soluble enzymes alone, since experience has shown that even minute contamination of the $S_{104}$ with microsomes resulted in sterol formation. The standard amount of microsome suspension $(0.2 \mathrm{ml}$.) used in most of our experiments was chosen to correspond approximately to the amount of microsomes present in $2.0 \mathrm{ml}$. of $\mathrm{S}_{10}$, but even a quarter of this amount was sufficient for nearly maximal activity of the enzyme system (cf. Table 2).

\section{Coenzymes needed for synthesis of sterol from mevalonic acid}

The results shown in Table 2 illustrate that after precipitation of the soluble proteins from $\mathrm{S}_{104}$ with ammonium sulphate and after reconstitution of the enzymes in $\mathrm{KHCO}_{3}$ solution and dialysis (see under Methods), the ability of the system to synthesize sterol was lost, but the full activity was regained on addition of the boiled protein-free extract of $\mathrm{S}_{104}$ and of DPN and ATP. Evidently the precipitation and dialysis removed coenzymes from the soluble enzyme fraction. From this experiment it could not be deduced whether the boiled extract contained all cofactors or not, since DPN and ATP were added to all flasks. Subsequent experiments were designed to determine the coenzymes needed in sterol synthesis.

It was commonly found that the fresh $S_{104}$ preparation combined with microsomes possessed maximal activity for sterol synthesis and that addition of known coenzymes such as DPN, TPN and ATP did not stimulate the synthetic activity; on the contrary they were often slightly inhibitory

Table 1. Sterol synthesis from mevalonic acid by centrifugal fractions of liver homogenates

Each flask contained: ATP, $2.5 \mu$ moles; DPN, $0.5 \mu$ mole; [2-14 $\mathrm{C}]$ mevalonic acid, $0.5 \mu$ mole $(0.024 \mu \mathrm{C})$, and $2.5 \mathrm{ml}$. of $\mathrm{S}_{10}$ or $\mathrm{S}_{104}$. Microsome suspensions $(0.2-1.0 \mathrm{ml}$.) were used as indicated. The final volume $(3.5 \mathrm{ml}$.) contained $0 \cdot 1$ M-potassium phosphate buffer, $\mathrm{pH} 7 \cdot 6$, nicotinamide $(0.03 \mathrm{M})$ and $\mathrm{MgCl}_{2}(0.004 \mathrm{M})$. Incubation was at $38^{\circ}$ for $2 \mathrm{hr}$.

\begin{tabular}{lc} 
Enzyme preparation used & $\begin{array}{c}\text { into sterol } \\
(\mu \mathrm{moles})\end{array}$ \\
$\mathrm{S}_{10}$ & 0.182 \\
$\mathrm{~S}_{104}$ & 0.000 \\
$\mathrm{~S}_{104}+$ 'light' microsomes $(0.2 \mathrm{ml})$. & $0 \cdot 178$ \\
$\mathrm{~S}_{104}+$ 'heavy' microsomes $(0.5 \mathrm{ml})$. & 0.018 \\
$\mathrm{~S}_{104}+$ 'light' $(0 \cdot 2 \mathrm{ml}$.$) and 'heavy'$ & 0.207 \\
(0.5 ml.) microsomes & 0.000 \\
'Light' microsomes (1.0 ml.) & 0.000 \\
'Heavy' microsomes (1.0 ml.) & 0.000 \\
'Light' +'heavy' microsomes & \\
(1 ml. of each) & \\
\hline
\end{tabular}

Mevalonic acid converted into sterol 0.000 $0 \cdot 178$ $0 \cdot 018$ 0.000 $0 \cdot 000$ $0 \cdot 000$

Table 2. Synthesis of sterol from mevalonic acid by fractions of liver homogenates

There were added to each flask: ATP, $2.5 \mu$ moles; DPN, $0.5 \mu$ mole and $\left[2{ }^{14} \mathrm{C}\right.$ ]mevalonic acid, $0.5 \mu$ mole; $2.5 \mathrm{ml}$. of $\mathrm{S}_{10}$ or $\mathrm{S}_{104}$ and $1 \mathrm{ml}$. of the soluble dialysed enzyme (S) were used as indicated. The final volume (3.5 ml.) was made up with standard buffer. Conditions otherwise were as for Expts. of Table 1.

$$
\begin{aligned}
& \text { Enzyme system used } \\
& \mathrm{S}_{10} \\
& \mathrm{~S}_{104}{ }^{*} \\
& \mathrm{~S}_{104}{ }^{*}+\text { microsomes }(0.05 \mathrm{ml} .) \\
& \mathrm{S}_{104}{ }^{*}+\text { microsomes }(0 \cdot 20 \mathrm{ml} .) \\
& \mathrm{S}_{104}{ }^{*}+\text { microsomes }(0 \cdot 50 \mathrm{ml} .) \\
& \mathrm{S} \dagger+\text { microsomes }(0 \cdot 20 \mathrm{ml} .) \\
& \mathrm{S} \dagger+\text { microsomes }(0 \cdot 20 \mathrm{ml} .)+ \\
& \text { boiled extract }(2 \cdot 0 \mathrm{ml} .)
\end{aligned}
$$

Mevalonic acid into sterol ( $\mu$ moles)

$0 \cdot 24$

$0 \cdot 00$

$0 \cdot 22$

$0 \cdot 24$

$0 \cdot 24$

$0 \cdot 00$

$0 \cdot 23$ converted
* $30.5 \mathrm{mg}$. protein $/ \mathrm{ml}$. $\quad$ † $45.0 \mathrm{mg}$. protein $/ \mathrm{ml}$. 
Table 3. Synthesis of sterols from mevalonic acid by fractions of liver homogenates

Each flask contained $2.5 \mathrm{ml}$. of $\mathrm{S}_{104}(\mathbf{2 4 . 5} \mathrm{mg}$. of protein/ ml.); suspension of washed microsomes $(0.2 \mathrm{ml}$.) and $\left[2-{ }^{14} \mathrm{C}\right]$ mevalonic acid $(0.5 \mu \mathrm{mole})$. The final volume $(3.5 \mathrm{ml}$.) was made up with standard buffer. Additions were as shown. Incubation was at $38^{\circ}$ for $2 \mathrm{hr}$.

\section{Mevalonic acid converted into sterol ( $\mu$ mole)} Additions

None

DPN $(0.5 \mu$ mole $)$

ATP (5 $\mu$ moles)

$0 \cdot 215$

$0 \cdot 199$

$0 \cdot 180$

$0 \cdot 194$

DPN + ATP

DPNH $(0.5 \mu \mathrm{mole})+$ ATP
From these and many other experiments in which boiled extracts of $\mathrm{S}_{104}$ were used to supply some of the coenzymes we could not find out whether ATP was an essential factor or not. If ATP was needed the boiled extract must have contained it in sufficient amounts to promote the synthesis. That the boiled extract contained some essential component other than ATP became clear very soon, because it could not be replaced by a combination of DPN, TPN (or their reduced forms) and ATP or other purine and pyrimidine nucleotides. That the essential factor contained in the boiled extract was not an inorganic ion, but some labile organic substance, was shown by the fact that the potency of the extracts deteriorated on storage for 2-3 weeks even at $-15^{\circ}$. Coenzyme A, when added in small amounts $(0.25-0.5 \mu$ mole) together with pyridine nucleotides and ATP, likewise could not replace the boiled extract; diphosphothiamine and lipoic acid were also ineffective in substituting for it. However, when cysteine was included in the test system, reactivation of sterol synthesis occurred without the addition of boiled extract. This is clearly shown by the experiment of Table 7, which in addition proved also the participation of ATP in the reactions (cf. last line in Table 7); AMP or ADP could not substitute for

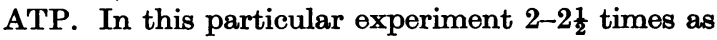
much mevalonic acid was converted into sterol in the presence of ATP $+\mathrm{CySH}$ or ATP $+\mathrm{CoA}+\mathrm{CySH}$ as on addition of a boiled extract 3 weeks old. This extract had deteriorated much during the storage, as formerly it supported the synthesis to about the same degree as the combination of $\mathrm{ATP}+\mathrm{CoA}+\mathrm{CySH}$. So far a complete dependence of sterol synthesis from mevalonic acid on CoA could not be demonstrated since $\mathrm{CySH}$ alone was nearly as effective as CySH + CoA. Nevertheless, the slight stimulation $(15-25 \%)$ caused by CoA (cf. Table 7) has been repeatedly observed. If CoA is an essential factor it must be attached to some part of the enzyme system.

\section{Further demonstration of requirement for adenosine triphosphate}

The need for ATP was demonstrated further in another set of experiments. For technical reasons during preparation of intermediates formed from mevalonic acid in the liver-enzyme system (G. Popják \& A. de Waard, unpublished work) the presence of high concentration of inorganic phosphate interfered with the procedures. For this reason attempts were made to prepare homogenates in $\mathrm{KCl}$-tris buffer, as described under Methods. Surprisingly, the enzyme systems so prepared $\left(\mathrm{S}_{104}+\right.$ microsomes) were completely inactive, in contrast with the preparations made in phosphate buffer. 
Table 5. Need for pyridine nucleotides in synthesis of sterol from mevalonic acid

Each flask contained soluble dialysed enzyme (S) (1 ml.; $21.5 \mathrm{mg}$. of protein $/ \mathrm{ml}$.), suspension of washed microsomes $(0.2 \mathrm{ml}$.) and [2-14 $\mathrm{C}]$ mevalonic acid $(0.5 \mu \mathrm{mole})$. Additions were as shown. The final volume $(3.5 \mathrm{ml}$.) was made up with standard buffer. Incubation was at $37^{\circ}$ for $1 \mathrm{hr}$. 'Boiled extract' is boiled protein-free extract of $S_{104}$.

\begin{tabular}{|c|}
\hline $\begin{array}{c}\text { Mevalonic acic } \\
\text { converted } \\
\text { into sterol } \\
(\mu \text { mole })\end{array}$ \\
\hline $\begin{array}{l}0.000 \\
0.005 \\
0.055 \\
0.119 \\
0.005 \\
0.077\end{array}$ \\
\hline
\end{tabular}

\section{Table 6. Need for pyridine nucleotides in synthesis of sterol from mevalonic acid}

The control flask (no. 1) contained fresh $\mathrm{S}_{104}(2.5 \mathrm{ml}$., $24 \mathrm{mg}$. of protein $/ \mathrm{ml}$.) $+0.2 \mathrm{ml}$. of microsomes $+\mathrm{DPNH}$ $(0.5 \mu \mathrm{mole})$. The experimental flasks (nos. 2-6) contained dialysed soluble enzyme (S), $1.0 \mathrm{ml}$. (40.5 mg. of protein/ $\mathrm{ml}$ ) $+\mathbf{0 . 2} \mathrm{ml}$. of washed microsomes. Additions to experimental flasks were: boiled extract $(2 \mathrm{ml}$.); DPNH $(0.5 \mu$ mole) reduced with alcohol dehydrogenase and ethanol; TPNH $(0.5 \mu \mathrm{mole})$ reduced with glucose 6-phosphate $(2 \mu$ moles $)$ and the specific dehydrogenase; ATP $(2.5 \mu$ moles). All flasks contained $0.5 \mu$ mole of [2-14 C]mevalonic acid. The final volume was $3.5 \mathrm{ml}$. made up with standard buffer. Incubation was for $1 \mathrm{hr}$. at $37^{\circ}$.

Mevalonic acid
converted
into sterol
( $\mu$ mole)
0.219
0.000
0.097
0.025
0.153
0.005

\section{Control}

\section{Additions}

2. Boiled extract

3. Boiled extract + DPNH

4. Boiled extract + TPNH

5. Boiled extract + DPNH + TPNH

6. $\mathrm{DPNH}+\mathrm{TPNH}+\mathrm{ATP}$

0.005

After several experiments, which need not be detailed, we established that the reason for this inactivation was the destruction of some of the coenzymes, but not of the enzymes, in the $S_{104}$ fraction during the few hours that elapsed between homogenizing and completion of the centrifugal fractionations. ATP was among the first to be destroyed, as the experiment recorded in Table 8 shows. All evidence indicates that the role of inorganic phosphate in securing active preparations of $\mathrm{S}_{104}$ is the inhibition of phosphatases. The experiment of Table 8 was carried out in two parts: (1) incubations were set up with $S_{10}$ within $1 \mathrm{hr}$. after making the homogenate; and (2) after a period of $2 \mathrm{hr}$. of 'ageing' of the $S_{10}$ at room temperature (i.e. $3 \mathrm{hr}$. after the homogenate was made). Comparison of the first and second column of figures in Table 8 shows that during the 'ageing' almost all ATP must have been destroyed in the preparation. It is of interest that the addition of ATP to the fresh preparation was inhibiting. Cysteine combined with ATP was likewise inhibiting in both preparations, whereas CoA showed a slight enhancing effect.

\section{Need for reducing agents for activation of synthesis of sterol}

Since CySH alone was nearly as effective as $\mathrm{CySH}$ plus $\mathrm{CoA}$ in activating the system consisting of the dialysed soluble enzymes + microsomes (cf.

\section{Table 7. Coenzyme requirements in synthesis of sterol from mevalonic acid}

Each flask contained: soluble dialysed enzyme (S), $1.0 \mathrm{ml}$. $(40.1 \mathrm{mg}$. of protein $/ \mathrm{ml}$.); washed microsomes, $0.2 \mathrm{ml}$; [ [2.14 C]mevalonic acid, $0.5 \mu$ mole. Additions, as shown, were: boiled extract, $2.0 \mathrm{ml}$; DPNH and TPNH, $0.5 \mu$ mole (both reduced with specific dehydrogenase and substrate); CoA, $0.5 \mu$ mole; ATP, $5 \mu$ moles; cysteine, $30 \mu$ moles. The final volume $(4 \mathrm{ml}$.) was made up with standard buffer. Incubations were for $1 \mathrm{hr}$. at $37^{\circ}$.

\section{Specific activity of sterol digitonides (counts/min. at infinite thickness)}

Additions

Boiled extract

Boiled extract + DPNH + TPNH 1200

DPNH + TPNH + ATP

$\mathrm{DPNH}+\mathrm{TPNH}+\mathrm{ATP}+\mathrm{CoA}$

DPNH + TPNH + ATP + CySH 2620

$\mathrm{DPNH}+\mathrm{TPNH}+\mathrm{ATP}+\mathrm{CySH}+\mathrm{CoA} \quad 3060^{*}$

$\mathrm{DPNH}+\mathrm{TPNH}+\mathrm{CySH}+\mathrm{CoA}$

8

* Equivalent to a conversion of $0.09 \mu$ mole of mevalonic acid into sterol.

Table 8. Dependence of synthesis of sterol from mevalonic acid on adenosine triphosphate

All flasks contained in a final volume of $3.5 \mathrm{ml}$. DPNH and TPNH, $0.5 \mu \mathrm{mole}$ each; $\left[2-{ }^{14} \mathrm{C}\right]$ mevalonic acid, $0.5 \mu \mathrm{mole}\left(0.1 \mu \mathrm{C}\right.$ of $\left.{ }^{14} \mathrm{C}\right) ; 350 \mu \mathrm{moles}$ of potassium phosphate, $\mathrm{pH} 7.6$; and $2.5 \mathrm{ml}$. of fresh $S_{10}$ or $2.5 \mathrm{ml}$. of $S_{10}$ 'aged' at room temp. for $2 \mathrm{hr}$. The $S_{10}$ was prepared from

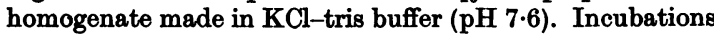
were at $37^{\circ}$ for $2 \mathrm{hr}$.

Experiment with

\begin{tabular}{|c|c|}
\hline \multicolumn{2}{|c|}{$\begin{array}{l}\text { Specific activity of } \\
\text { sterol digitonides } \\
\text { (counts/min. at } \\
\text { infinite thickness) }\end{array}$} \\
\hline $4328^{*}$ & 22 \\
\hline 2865 & 3871 \\
\hline 3489 & 4165 \\
\hline 2495 & 2212 \\
\hline
\end{tabular}

Non

Additions

ATP (5 $\mu$ moles)

$\mathrm{ATP}+\mathrm{CoA}(0.5 \mu \mathrm{mole})$

ATP + CySH (30 $\mu$ moles)

4165

* Equivalent to a conversion of $0.118 \mu$ mole of mevalonic acid into sterol. 
Table 7), it was of interest to determine what other substances with properties similar to that of CySH might fulfil the same role. The results of experiments shown in Table 9 demonstrated that $\beta$ mercaptoethylamine (cysteamine), GSH and ascorbic acid (as the potassium salt) had effects

Table 9. Effectiveness of reducing agents to activate synthesis of sterol in the absence of boiled extract of $S_{104}$

Each flask contained the standard incubation mixture (see under Methods) with $0.5 \mu \mathrm{mole}$ of $\left[2{ }^{14} \mathrm{C}\right]$ mevalonic acid. Additions of CSH, GSH and ascorbate $(30 \mu$ moles each) and of CoA $(0.5 \mu \mathrm{mole})$ were made as shown. When boiled extracts of $\mathrm{S}_{104}$ were used, the standard phosphate buffer of the standard incubation mixture was replaced by $2.0 \mathrm{ml}$. of boiled extract. Incubations were at $37^{\circ}$ for $1 \mathrm{hr}$. The three experiments recorded were done at different times with different enzymes.

\begin{tabular}{|c|c|c|}
\hline Expt. & Additions & $\begin{array}{l}\text { converted } \\
\text { into sterol } \\
(\mathrm{m} \mu \text { moles })\end{array}$ \\
\hline$A$ & $\begin{array}{l}\text { None } \\
\text { Boiled extract* } \\
\text { GSH } \\
\text { GSH + CoA } \\
\text { CySH } \\
\text { CySH + CoA } \\
\text { Boiled extract* + GSH }\end{array}$ & $\begin{array}{r}0 \\
0 \\
44 \\
59 \\
42 \\
42 \\
55\end{array}$ \\
\hline$B$ & $\begin{array}{l}\text { Boiled extract } \dagger \\
\text { CoA }(0 \cdot 5 \text { and } 2 \mu \text { moles }) \\
\text { GSH }+\mathrm{CoA} \\
\text { CySH }+\mathrm{CoA} \\
\text { Cysteamine }+\mathrm{CoA} \\
\text { Boiled extract } \dagger+\text { cysteamine }\end{array}$ & $\begin{array}{r}57 \\
0 \\
154 \\
91 \\
47 \\
138\end{array}$ \\
\hline$C$ & $\begin{array}{l}\text { GSH } \\
\text { Ascorbate } \\
\text { GSH + ascorbate }\end{array}$ & $\begin{array}{r}107 \\
113 \\
98\end{array}$ \\
\hline
\end{tabular}

Table 10. Effects of glutathione and gas phase on synthesis of squalene and sterol from $\left[2-{ }^{14} \mathrm{C}\right]$ mevalonic acid

Standard incubation mixtures with $0.5 \mu$ mole of $\left[2-{ }^{14} \mathrm{C}\right]-$ mevalonic acid $\left(0 \cdot 1 \mu \mathrm{c}\right.$ of $\left.{ }^{14} \mathrm{C}\right)$. Each flask contained $10 \mathrm{mg}$. of squalene from the start. Glutathione (GSH; $30 \mu$ moles) was added as shown. In the anaerobic experiments the flasks were being flushed through continuously with $\mathrm{N}_{2}$.

$\begin{array}{cccc}\text { Addition } & \text { Gas phase } & \overbrace{\text { Squalene }}^{\text {Total }{ }^{14} \mathrm{C} \text { counts found in }} & \begin{array}{c}\text { Sterol } \\ \text { digitonides }\end{array} \\ \text { None } & \text { Air } & 0 & 0 \\ \text { GSH } & \text { Air } & 5130 & 15771 \\ \text { None } & \mathrm{N}_{2} & 44000 & 0 \\ \text { GSH } & \mathrm{N}_{2} & 48690^{*} & 1288\end{array}$
acid.

* Corresponds to a utilization of $0.19 \mu$ mole of mevalonic qualitatively similar to that of CySH; maximum activity of the enzyme system was observed in the presence of GSH or of ascorbic acid. The combination of CoA with these reducing agents had either no effect or only a slight enhancing effect on sterol synthesis.

In the activated enzyme system in the presence of air, both squalene and sterol are synthesized from $\left[2-{ }^{14} \mathrm{C}\right]$ mevalonic acid, most of the ${ }^{14} \mathrm{C}$ appearing in sterol (cf. Table 10); under $\mathrm{N}_{2}$, however, only squalene is formed. The experiment recorded in Table 10 also shows that aerobically neither squalene nor sterol is synthesized if the reducing agent (e.g. GSH) is omitted from the incubation. On the other hand, squalene is formed anaerobically even if the reducing agent is not added.

In order to decide whether the enzyme or coenzyme protected by the reducing agents is involved in the reactions preceding the formation of squalene or in the cyclization of the latter to sterol, a set of experiments were carried out in which the enzyme system was incubated with all the cofactors (standard incubation mixture), but without a reducing agent, for $1 \mathrm{hr}$. under $\mathrm{N}_{2}$. During this time synthesis of squalene alone was expected to occur. Then the $\mathrm{N}_{2}$ was replaced by air and the incubation continued for another hour (Table 11). When pyridine nucleotides were not added at the beginning of the aerobic period (second hr.) only a small amount of radioactive sterol appeared even if GSH had been added at that time. However, when the addition of DPNH and TPN was repeated on admission of air, an appreciable amount of the squalene synthesized during the anaerobic period was converted into sterol during the second hour even in the absence of glutathione or of ascorbic acid (Table 11, Expt. B). The synthesis of squalene and of sterol usually stops at the end of $1 \mathrm{hr}$. (cf. Table 11, Expt. A); it is our impression that this is due to the exhaustion of coenzymes, DPNH, TPN and of ATP.

The conclusion drawn from the experiments recorded in Tables 10 and 11 is that glutathione or ascorbic acid protects from oxidation an enzyme or coenzyme involved in the reactions leading to the synthesis of squalene from mevalonic acid and not in the cyclization of squalene to sterol. We examined further the cofactor requirements for the anaerobic formation of squalene. The experiment of Table 12 shows the absolute need for ATP and pyridine nucleotides; the small amount of squalene formed in the absence of added DPN or TPN may be accounted for by the presence of traces of these coenzymes in the enzyme preparation. Neither DPN nor TPN appeared specific for squalene synthesis, but maximal conversion of MVA into squalene occurred when both were present together. 
Table 11. Synthesis of squalene and of sterol from mevalonic acid in the absence of reducing agent

Each flask contained the standard incubation mixture with $0.5 \mu$ mole of $\left[2-{ }^{14} \mathrm{C}\right]$ mevalonic acid $\left(0 \cdot 1 \mu \mathrm{c}{ }^{14} \mathrm{C}\right)$. Additions of GSH and of ascorbate $(30 \mu$ moles each), DPNH $(1 \mu$ mole) and of TPN $(0.5 \mu \mathrm{mole})$ were made as shown. During the anaerobic period of incubations the flasks were flushed continuously with $\mathrm{N}_{2}$. Experiments $A$ and $B$ were done separately with different enzyme preparations, neither of which was particularly active.

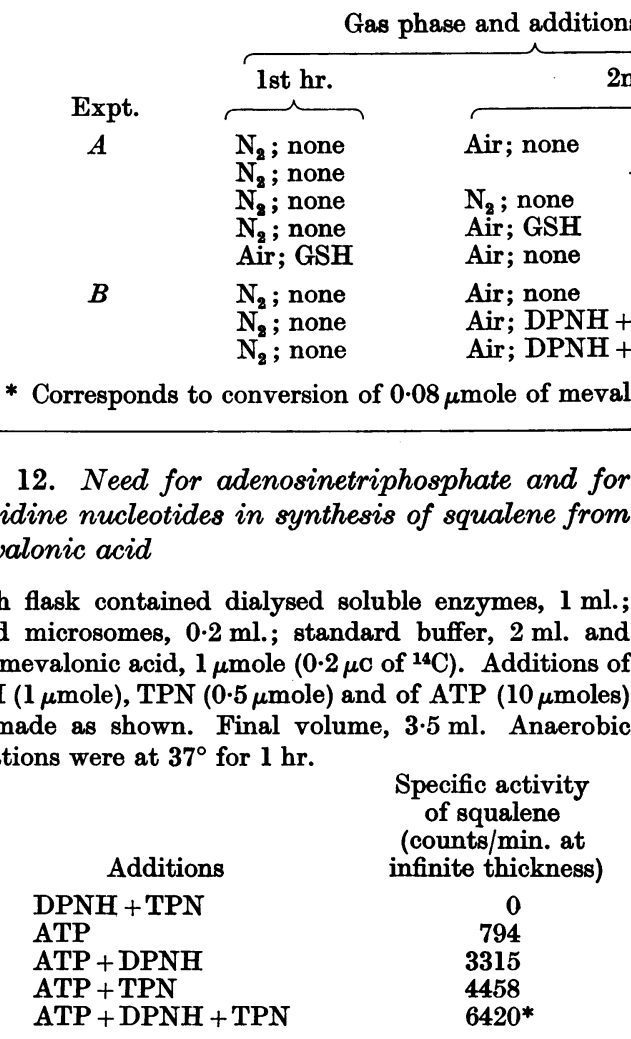

* Equivalent to conversion of $0.25 \mu$ mole of mevalonic acid.

\section{Effect of $S H$-inhibitors on synthesis of squalene and of sterol from mevalonic acid}

As it seemed likely that the oxygen-sensitive substance in the enzyme system was an SHcompound, the effects of $\mathrm{HgCl}_{2}$ and of $p$-chloromercuribenzoate (PCMB) on squalene synthesis were investigated. It was found that both mercurials in a concentration of $10^{-3} \mathrm{M}$ almost completely abolished the formation of squalene under anaerobic conditions. As might be expected, glutathione, when added to the incubation mixture after PCMB and before the introduction of the enzymes, partly counteracted the inhibition caused by the mercurial compound. Ascorbate, on the other hand, gave no protection against PCMB (Table 13).

By the next set of experiments we have been

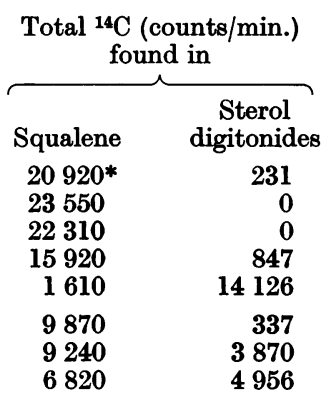

$\dagger$ Incubation for $1 \mathrm{hr}$. only. able to show that the components of the system sensitive to PCMB were present mainly in the microsomes. For this purpose $0.2 \mathrm{ml}$. of the microsomal suspension was added to $2 \mathrm{ml}$. of standard buffer containing $4 \mu$ moles of PCMB; the mixture was left for $3 \mathrm{~min}$. packed in ice. Thereafter $30 \mu$ moles of GSH were added, followed after $1 \mathrm{~min}$. by DPNH, TPN, ATP, $1 \mathrm{ml}$. of soluble enzyme and $\left[2{ }^{14} \mathrm{C}\right]$ mevalonic acid; the mixture was then incubated aerobically for $1 \mathrm{hr}$. The formation of sterol in this system was compared with that in another system in which the soluble enzyme ( $1 \mathrm{ml}$. in $2 \mathrm{ml}$. of buffer) was pretreated with $4 \mu$ moles of PCMB for $3 \mathrm{~min}$. at $0^{\circ}$; the addition of GSH (30 $\mu$ moles), DPNH, TPN, ATP, microsomes $(0.2 \mathrm{ml}$.$) and of \left[2 .{ }^{14} \mathrm{C}\right]$ mevalonic acid, in that order, completed the system. A control, without PCMB, containing the standard incubation mixture with $30 \mu$ moles of GSH was included. All three incubations were set up in duplicates which in addition to GSH contained also $0.5 \mu \mathrm{mole}$ of $\mathrm{CoA}$. In order to avoid the possibility of sampling errors, the pretreatment of microsomes and of the soluble enzyme with PCMB was made on a scale large enough to pipette accurately the same enzyme preparation into the duplicate flasks; so that any effect of CoA would not be masked by slight inaccuracies of pipetting of the enzymes and of PCMB.

As shown in Table 14 there was nearly complete failure of sterol synthesis in the system containing the microsomes pretreated with PCMB. In the system containing the pretreated soluble enzyme only $50 \%$ inhibition was observed. CoA, in both the control system and in the one containing the pretreated soluble enzyme, caused about $20 \%$ stimulation; with the pretreated microsomes CoA did not increase sterol synthesis. 


\section{Optimum conditions for synthesis of sterol from mevalonic acid}

The effect of $\mathrm{pH}$ on synthesis of sterol was studied in the $\mathrm{pH}$ range $6 \cdot 5-8 \cdot 3$. This range was covered by potassium phosphate buffer $(6 \cdot 5-7 \cdot 6)$

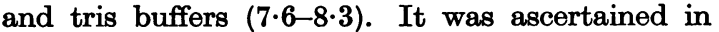
separate experiments, not recorded here, that tris buffer had no effect other than that attributable to

\section{Table 13. Effect of $S H$-inhibitors on} synthesis of squalene

Standard incubation mixtures with $0.5 \mu$ mole of $\left[2-{ }^{14} \mathrm{C}\right]$ mevalonic acid $\left(0 \cdot 1 \mu \mathrm{C}\right.$ of $\left.{ }^{14} \mathrm{C}\right)$. Additions of $\mathrm{HgCl}_{2}$ and of $p$-chloromercuribenzoate (PCMB) were made as indicated. At the end of incubation ( $1 \mathrm{hr}$. under $\mathrm{N}_{2}$ and $\left.37^{\circ}\right) 10 \mathrm{mg}$. of carrier squalene was added to each flask. Experiments $A$ and $B$ were done with two different enzyme preparations.

Expt.

\section{A None; control}

$\mathrm{HgCl}_{2}(4 \mu$ moles; $\mathrm{mm})$

PCMB ( $4 \mu$ moles)

PCMB ( $20 \mu$ moles $)$

*PCMB $(20 \mu$ moles $)+$ GSH

(30 $\mu$ moles)

Control + GSH (30 $\mu$ moles $)$

$B \quad$ None; control

*PCMB (20 $\mu$ moles $)+$ ascorbate

(30 $\mu$ moles)

* The PCMB and glutathione (GSH) or ascorbate were added to the incubation mixture before the introduction of soluble enzyme fraction or microsomes.

Table 14. Effect of $S H$-inhibitors on synthesis of sterol and localization of inhibited substance in the microsomes

The control flasks ( $1 a$ and $1 b)$ contained standard incubation mixture with $0.5 \mu$ mole of [2-14 $\mathrm{C}$ ]mevalonic acid $\left(0 \cdot 1 \mu \mathrm{C}\right.$ of $\left.{ }^{14} \mathrm{C}\right)$ and $30 \mu$ moles of GSH. In flasks $2 a$ and $2 b$ the soluble enzyme, and in flasks $3 a$ and $3 b$ the microsomes, were pretreated with $4 \mu \mathrm{moles}$ of PCMB; otherwise all the components were the same as in the control. CoA $(0.5 \mu$ mole) was added as shown. The final volume was $4 \mathrm{ml}$. in all flasks. For details of experiment see text. Incubations were at $37^{\circ}$ for $1 \mathrm{hr}$.; gas phase: air.

\section{Experimental conditions}

la. Control

Specific activity of sterol digitonides (counts/min. at infinite thickness)

1b. Control + $\mathrm{CoA}$ 3430

2a. Soluble enzyme pretreated with 4611 PCMB

2b. Same as $2 a+\mathrm{CoA}$ 1859

3a. Microsomes pretreated with PCMB

3b. Same as $3 a+\mathrm{CoA}$
pH. The soluble enzyme and microsomes for these experiments were prepared in the usual way; the desired $\mathrm{pH}$ was obtained by combining $1 \mathrm{ml}$. of the dialysed soluble enzyme and $0.2 \mathrm{ml}$. of the microsomal suspension with either $2 \mathrm{ml}$. of $0.1 \mathrm{M}$ potassium phosphate buffers ( $\mathrm{pH}$ values $6-8$ ) or $2 \mathrm{ml}$. of $0 \cdot 154 \mathrm{M}-\mathrm{KCl}$-tris buffers ( $\mathrm{pH}$ values $7 \cdot 6$ 9.5). Nicotinamide $(0.03 \mathrm{M})$ and $\mathrm{MgCl}_{2}(0.004 \mathrm{M})$ were added to both types of buffers. When buffers with a $\mathrm{pH}$ lower than 7.0 were used, the final $\mathrm{pH}$ (measured with a glass electrode) was higher than that of the buffer added; with buffers which had a pH higher than $7 \cdot 6$, the final $\mathrm{pH}$ of the incubation mixture was lower than that of the buffer added. Fig. $1 a$ shows that the optimum $\mathrm{pH}$ for sterol synthesis lies in the range $7 \cdot 3-7 \cdot 5$, the utilization of mevalonic acid falling off sharply both on the acid and alkaline side of this range.

The dependence of sterol synthesis on the amounts of ascorbate, ATP, and mevalonic acid are shown in Fig. $1 b-d$. The amount of mevalonic
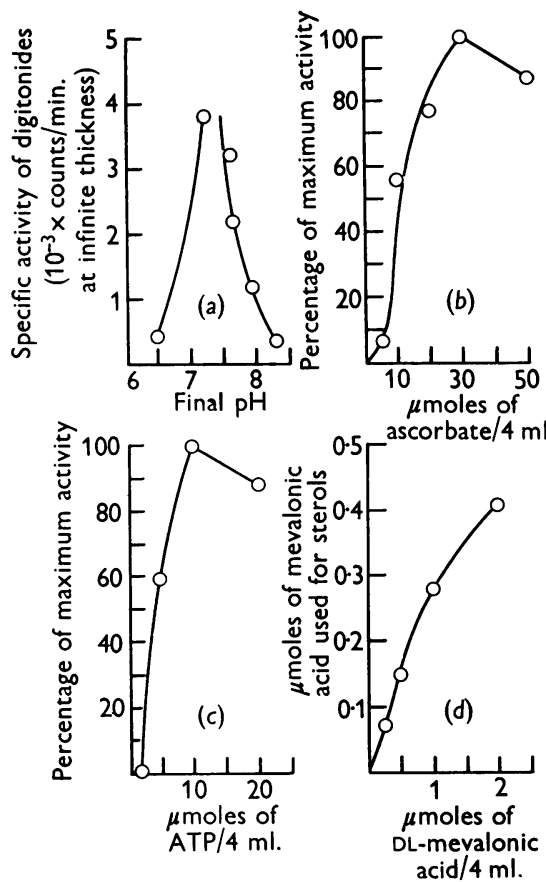

Fig. 1. Determination of optimum conditions for synthesis of sterol from mevalonic acid: (a) dependence of synthesis on $\mathrm{pH}$ of medium; standard incubation mixtures were used (with the exception of buffer, for which see text) with $30 \mu$ moles of ascorbate and $0.5 \mu$ mole of mevalonic acid; $(b),(c)$ and $(d)$ effects of increasing concentrations of ascorbate, ATP and of mevalonic acid respectively on synthesis of sterol. In all these experiments the conditions of standard incubations were used except for the concentration of one component that was being varied. 
acid converted into sterol increased almost linearly as the amount of the acid added was increased from 0.25 to $1 \mu$ mole; a saturation value was not reached even with $2 \mu$ moles of the acid.

The concentration of pyridine nucleotides in the incubation mixture was in no way critical; for example, when the amount of DPNH added to a standard incubation mixture, containing $30 \mu \mathrm{moles}$ of ascorbate and $0.5 \mu \mathrm{mole}$ of TPN, was increased from 0.25 to $0.5,1.0$ and $2 \mu$ moles, the percentage conversion of mevalonic acid into sterol increased from $34 \cdot 3$ to $35 \cdot 8,36 \cdot 3$ and $37.9 \%$ respectively.

The presence of nicotinamide was essential in the incubation mixture; in its absence both DPN and TPN were rapidly destroyed and very little sterol was synthesized. This destruction is almost entirely attributable to the action of microsomes, which $(0.2 \mathrm{ml}$. in $3 \mathrm{ml}$. of buffer) in the absence of nicotinamide can inactivate micromole quantities of DPN and TPN within a few minutes even at room temperature, as determined in the spectrophotometer with the aid of specific dehydrogenases.

On the basis of these experiments the following incubation mixture in a final volume of $4 \mathrm{ml}$. was established as nearly optimum for sterol synthesis with the crude enzyme preparations: DPNH $1 \mu$ mole, TPN $0.5 \mu$ mole, ATP $10 \mu$ moles, GSH or potassium ascorbate $30 \mu \mathrm{moles}$, soluble enzymes $30-50 \mathrm{mg}$. (in $1 \mathrm{ml}$. of $0.02 \mathrm{M}-\mathrm{KHCO}_{3}$ ), suspension of washed microsomes $0.2 \mathrm{ml}$., [2-14 $\mathrm{C}]$ mevalonic acid $\mathbf{0 . 5} \mu \mathrm{mole}$ (restricted for sake of economy), nicotinamide $120 \mu$ moles, $\mathrm{MgCl}_{2} 16 \mu$ moles, and potassium phosphate buffer $400 \mu$ moles, final pH 7.4; gas phase, air. If the synthesis of squalene alone is desired the incubations should be done in the absence of oxygen; GSH or ascorbate is then not an essential component of the system, although the presence of either improves slightly the yield of squalene, even anaerobically.

\section{DISCUSSION}

The enzyme system investigated, which uses mevalonic acid as substrate for sterol synthesis, may be divided into two parts: the squalenesynthesizing system and the part effecting the cyclization of squalene to sterol; it contains the same components of the liver cell as were found by Bucher \& McGarrahan (1956) to be necessary for sterol synthesis from acetate. Although the synthesis of squalene from mevalonic acid was observed with the soluble $\left(S_{104}\right)$ preparations alone, incubation mixtures containing both microsomes and soluble enzymes were more efficient in this respect, provided that oxygen was excluded from the incubations, for aerobically the main product of synthesis from mevalonic acid was sterol. We have never observed the formation of sterol in the absence of microsomes, neither did we succeed in getting the microsomal enzymes into solution by repeated freezing and thawing or by lysis with water; acetone-dried powders of microsomes made with acetone chilled to $-20^{\circ}$ failed also to give an active preparation catalysing the formation of sterol from mevalonic acid in the presence of fresh $\mathrm{S}_{104}$ enzymes.

The squalene-synthesizing component of the liver-enzyme system is similar in respect of its coenzyme requirements to the squalene-synthesizing system prepared by Amdur, Rilling \& Bloch (1957) from baker's yeast in that it requires both pyridine nucleotides and ATP for the synthesis of squalene from mevalonic acid, but it differs from the yeast enzymes by a component which is extremely sensitive to oxidation and which according to the experimental evidence is an SH-compound and is present in the microsomes. This $\mathrm{SH}$ compound can be well protected and kept in the active form by reducing substances such as cysteine, cysteamine, glutathione and ascorbic acid; it is involved in the reactions preceding the formation of squalene. The evidence for the latter conclusion came from several observations: $(a)$ cyclization of squalene to sterol occurred in the presence of oxygen and in the absence of a reducing agent (Table 11); (b) squalene was not formed under aerobic conditions unless a reducing agent was present (Table 10); (c) the anaerobic synthesis of squalene, which did not require a reducing substance, was completely inhibited by $\mathrm{mm}-\mathrm{HgCl}_{2}$ or $p$-chloromercuribenzoate (Table 13). This SHcompound might be an SH-enzyme or a coenzyme. Clear-cut evidence for the participation of $\mathrm{CoA}$ could not so far be obtained, but, as indicated in several experiments, the addition of $0.5 \mu$ mole of CoA to the incubation mixtures had a slight (15$25 \%$ ) enhancing effect on sterol or squalene synthesis. That effects greater than this were not observed need not argue against the participation of CoA-SH, since most of the enzyme preparations used in the course of this investigation exhibited high activity. It may be relevant that an $\mathrm{SH}$ compound, whose identity has not yet been established, can be extracted with hot water from the microsomes. This aqueous extract of microsomes absorbed ultraviolet light between 240 and $270 \mathrm{~m} \mu$ with a maximum at 260 , and shoulders at 267, 255 and in one instance at $250 \mathrm{~m} \mu$. Assuming that all the absorption at $260 \mathrm{~m} \mu$ was due to adenine $\left(\epsilon, 1.58 \times 10^{4}\right)$, then the molar ratio of adenine to free - $\mathrm{SH}$ in the extracts was about 10:1. By assaying the free -SH content of the extracts against a solution of cysteine we calculated that the standard amount of microsomes used in the incubations would contain $0.2-0.25 \mu$ mole of this SH-compound assuming one SH-group per 
molecule. The experimental evidence available suggests, but does not prove the participation of CoA.

The need for ATP may be explained by an activation reaction of mevalonic acid, or of another substance derived from it, with CoA-SH or by the formation of a phosphorylated intermediate; the latter has been suggested by Amdur et al. (1957) to occur in the yeast-enzyme preparation synthesizing squalene.

It is difficult to obtain clear-cut evidence in a crude multi-enzyme system, such as the one used by us, as to the reactions in which the pyridine nucleotides participate. We have not been able to show so far in the spectrophotometer the oxidation or reduction of the reduced or oxidized forms of DPN or TPN in the course of squalene or sterol synthesis from mevalonic acid. We found that DPNH rather than DPN was required (cf. Table 5), but it was more difficult to obtain evidence showing whether TPN or TPNH (or both forms) were preferred by the system. This difficulty arose because even in the absence of an added specific substrate, such as glucose 6-phosphate, TPNH was always formed from TPN in our enzyme system in the presence of ATP. It is probable that glycolytic enzymes are present in the preparations and small amounts of glycogen are inevitably introduced with the microsomes; thus glucose 6-phosphate may be formed and act as substrate for glucose 6-phosphate dehydrogenase, which is present in the soluble enzyme fraction in substantial amounts. The experiment recorded in Table 15 suggests that probably optimum conditions prevail when both TPN and TPNH are present in the system. In this set of experiments we made use of the powerful TPNH-specific glutathione reductase (Mapson \& Goddard, 1951) found in the dialysed soluble enzyme, to keep TPN in the oxidized form. As the data show, the specific activity of the digitonides was the lowest in the incubation containing

Table 15. Effect of keeping triphosphopyridine nucleotide in oxidized form on synthesis of sterol from mevalonic acid

Standard incubation mixtures with $0.5 \mu$ mole of [2-14 $\mathrm{C}$ mevalonic acid $\left(0 \cdot 1 \mu \mathrm{O}\right.$ of $\left.{ }^{14} \mathrm{C}\right)$ plus $30 \mu$ moles of potassium ascorbate in each flask. Additions were as shown. Aerobic incubation was for $1 \mathrm{hr}$. at $37^{\circ}$. GSSG represents oxidized glutathione.

\section{Additions \\ ( $\mu$ moles)}

None

Glucose 6-phosphate (1.0)

Glucose 6-phosphate (1.0) + GSSG (4.0) GSSG (4.0) oxidized glutathione and no added glucose 6phosphate.

Both DPN and TPN are required not only in the synthesis of squalene from mevalonic acid but also in the conversion of squalene into sterol; in experiments of the same design as that shown in Table 11 (Expt. B) the conversion of squalene, formed during an anaerobic period, into sterol after admission of air was much poorer when only DPNH or TPN was added than on introduction of both coenzymes. This observation is in general agreement with the finding of Tchen \& Bloch (1957), who studied the cyclization of squalene in liver preparations, although these authors reported that they had the impression from their experiments that a TPNHgenerating system was more efficient than DPNH in promoting the cyclization of squalene.

\section{SUMMARY}

1. The biosynthesis of squalene and of sterol from [2-14 C]mevalonic acid (3-hydroxy-3-methyl[2-14 C]pentano-5-lactone) has been studied in liverenzyme preparations consisting of the soluble protein fraction $\left(\mathrm{S}_{104}\right)$ of homogenates and of microsomes.

2. Most of the coenzymes needed in sterol and squalene synthesis can be removed from the $S_{104}$ by precipitation of the proteins with ammonium sulphate, followed by reconstitution of the proteins in 0.02 $\mathrm{M}$-potassium hydrogen carbonate and by dialysis.

3. It was shown that diphosphopyridine nucleotide, triphosphopyridine nucleotide and adenosine triphosphate are required for the synthesis of squalene and sterol from mevalonic acid. In addition, the microsomes contain an SH-compound, highly sensitive to oxidation, and which is essential in the reactions preceding the formation of squalene.

4. Under aerobic conditions the microsomal SH-compound must be protected by reducing agents such as glutathione or ascorbic acid, otherwise neither squalene nor sterol is formed. Under anaerobic conditions only squalene is synthesized and a reducing agent is not required. The squalene formed anaerobically (in the absence of glutathione or ascorbate) may be cyclized to sterol after admission of air to the incubation flasks by repeated addition of diphosphopyridine and triphosphopyridine nucleotides.

5. The anaerobic synthesis of squalene is strongly inhibited by mM-mercuric chloride or $p$-chloromercuribenzoate. Glutathione, but not ascorbic acid, partially protects the synthesis against this inhibition.

6. The evidence suggests, but does not prove, that the microsomal SH-compound is coenzyme $\mathbf{A}$. 
We are indebted to Dr Rita H. Cornforth of the National Institute for Medical Research for the synthesis of [2-14 C]mevalonic acid; to Professor A. Wormall, F.R.S., for a gift of squalene and to Horlicks Ltd. for a supply of $\beta$-mercaptoethylamine (Becaptan). The spectroscopic examination of the microsomes were done by $\operatorname{Dr} F$. A. Holton. It is a pleasure to acknowledge the skilled technical assistance of Mr K. Clifford and Mr T. Flynn. A grant from the Eli Lilly Foundation to the Medical Research Council for the purchase of our Spinco Model L centrifuge is also gratefully acknowledged.

\section{REFERENCES}

Amdur, B. H., Rilling, H. \& Bloch, K. (1957). J. Amer. chem. Soc. 79, 2647.

Bucher, N. L. R. \& McGarrahan, K. (1956). J. biol. Chem. 222, 1.

Cornforth, J. W., Cornforth, R. H., Popják, G. \& Gore, I. Youhotsky (1957). Biochem. J. 66, 10 P.
Cornforth, J. W., Cornforth, R. H., Popják, G. \& Gore, I. Youhotsky (1958). Biochem. J. 69, 146.

Gornall, A. G., Bardawill, C. J. \& David, M. M. (1949). J. biol. Chem. 177, 751.

Gould, R. G. \& Popják, G. (1957). Biochem. J. 66, 51 P.

Hele, P., Popják, G. \& Lauryssens, M. (1957). Biochem. J. 65, 348.

Mapson, L. W. \& Goddard, D. R. (1951). Biochem. J. 49, 592.

Popják, G. (1950). Biochem. J. 46, 560.

Popják, G. (1954). Arch. Biochem. Biophys. 48, 102.

Popják, G., Gosselin, L. \& Gore, I. Youhotsky (1958). Biochem. J. 68, 15 P.

Strittmatter, C. F. \& Ball, E. G. (1954). J. cell. comp. Physiol. 43, 57.

Tavormina, P. A., Gibbs, M. H. \& Huff, J. W. (1956). J. Amer. chem. Soc. 78, 4498.

Tchen, T. T. \& Bloch, K. (1957). J. biol. Chem. 226, 931.

\title{
The Nature of the Thyroid Auto-antibodies Present in Patients with Hashimoto's Thyroiditis (Lymphadenoid Goitre)
}

\author{
By I. M. ROITT, P. N. CAMPBELL AND DEBORAH DONIACH \\ Courtauld Institute of Biochemistry and Institute for Clinical Research, The Middlesex \\ Hospital Medical School, London, W. 1
}

(Received 7 October 1957)

The chronic disease of the thyroid known as Hashimoto's thryoiditis is characterized by invasion of the gland with lymphoid tissue and plasma cells which gradually proliferate and replace the normal follicular structure, giving rise to thyroid deficiency in the patient. The serum of these patients contains abnormally raised concentrations of $\gamma$-globulins and these have been shown to reflect the presence of precipitating autoantibodies against thyroglobulin, the specific protein (or proteins) in which the thyroid hormones are stored in the colloid of the thyroid follicles (Roitt, Doniach, Campbell \& Hudson, 1956); (Doniach \& Roitt, 1957).

It may be postulated that the confinement of thyroglobulin in closed follicles prevents the establishment of immunological tolerance in early life so that any subsequent release of thyroglobulin might set up an auto-immunization process. This could be responsible for the gradual destruction of the gland by a self-perpetuating chain reaction in which further release of colloid from follicles damaged by interaction with antibody leads to enhancement of the immunity. The finding by Witebsky, Rose, Terplan, Paine \& Egan (1957) that the formation of auto-antibodies against thyroid extracts could be induced in rabbits, dogs and guinea pigs and that this led to thyroiditis lends support to the hypothesis that a similar sequence of events occurs in the human in Hashimoto's disease.

The level of antibody found in the sera of patients with Hashimoto's thyroiditis affords an opportunity to study the characteristics not only of an auto-antibody but also of a human precipitating antibody.

A preliminary account of some aspects of this work has already appeared (Roitt, Doniach \& Campbell, 1956).

\section{MATERIALS AND METHODS}

Radioactive compound. Algal protein hydrolysate containing a mixture of $\left.{ }^{14} \mathrm{C}\right]$ amino acids $(100 \mu \mathrm{C} \equiv 2.5 \mathrm{mg}$.) was obtained from The Radiochemical Centre, Amersham, Bucks.

Sera containing the auto-antibody. These were obtained from patients with lymphadenoid goitre, untreated or treated with thyroid hormones, but not subjected to surgery, since the antibody content of thyroidectomized patients is low.

Rabbit antisera. Rabbits were immunized against human $\gamma$-globulin (kindly given by $\operatorname{Dr}$ R. A. Kekwick) and against pooled Hashimoto sera by means of a Freund-type adjuvant (Freund \& McDermott, 1942). The animals were injected subcutaneously at several sites with an emulsion of antigenstock adjuvant mixture $(1: 3, \mathrm{v} / \mathrm{v})$. The stock mixture was prepared by homogenizing 1 vol. of Arlacel A (Atlas 